Journal of Engineering and Applied Sciences 14 (Special Issue 9): 10579-10588, 2019

ISSN: 1816-949X

(C) Medwell Journals, 2019

\title{
Reinforcement of Condensation Reaction using DCCI to Synthesis New Compounds Derived from Phthalyl Dl-Leucine and Sulfa Drugs
}

\author{
Bushra K. Al-Salami, Hanan A. Al-Hazam and Yossra A. Marich \\ Department of Chemistry, College of Science, University of Basrah, Basrah, Iraq
}

\begin{abstract}
New compounds derived from N-phthalyl DL-leucine as amino acid derivative and some kinds of sulfa drugs like sulfanilamide, sulfaisoxazole, sulfamethaxzole, sulfadiazine, sulfathaizole, sulfapyridine and sulfacetamide sodium were prepared by utilizing N, N-Dicyclohexylcarbodimide (DCCI) as condensing agent to promoted condensation reaction to appointed the corresponding amide. All the synthesized compounds have been characterizated by elemental analysis (C, H, N, S), FT-IR and H NMR. The antimicrobial activity of these compounds were determined against two kinds of bacteria gram positive (Staphylococcus aures) and gram negative (Aerompanas veronil) by using different concentration of each synthesized compound in addition the MIC was determined.
\end{abstract}

Key words: N-phthalyl, DL-leucine, sulfa drugs, DCCI, amide, sulfamethaxzole, antimicrobial

\section{INTRODUCTION}

Amino acids constitute an important class of nitrogen-containing, naturally occurring compounds. Also it can be called $\alpha$-amino acid because every amino acid has a carboxyl group - $\mathrm{COOH}$ and an amino group $\mathrm{NH}_{2}$ and each group can exist in an acidic from or a basic from depending on the $\mathrm{Ph}$ of the solution in which the amino acid is dissolved. The biological function of amino acids is well established they are the constituent monomer units from which the biopolymers based on the peptide bond are built, for example, polypeptides and proteins including enzyme (Fox and Whitesell, 2004). Peptides and protiens are polymers of amino acids linked together by amide bond. Gramicidin $\mathrm{S}$ is an example of antibiotic peptide produced by a strain of bacteria, it is a cyclic decapeptide that contains Orithine and some amino acids such as L-phenylalanine, L-valine and L-Leucine (Bruice, 2004). Another examples of amino acids derivatives is penicillin (Lipmann et al., 1941). Moreover the amino acids can enter into many reaction with some metals to form many types of complexes (Al-Salami et al., 2017). The first antibiotics are sulfonamide commonly known as Sulfa drugs were introduced clinically in 1934 as the first effective antibiotics. Sulfa drugs such as sulfanilamide is a bacteriostatic drug which inhibits the further growth of bacteria.

The effect of the sulfa drugs is inhibition the bacterial enzyme that synthesizes folic acid of that bacteria (Otten, 1986, Tilles, 2001). Sulfa drugs are widespread among many compounds which possess many requisition like diuretic or antiglaucoma, also many kinds of sulfa drugs such as sulfadiazine used for treatment of anthrax and urinary tract infection and prevent incidence of a meningococcal carriers (Hassan et al., 1974; Schabel et al., 1946).

The newfangled study of this research localize about the formation of amide from amino acid derivative, phthalyl DL-leucine and selected sulfa drugs by using N, $\mathrm{N}$-Dicydohexylcarbodiimide (DCCI) as condensing agent to furnish the coinciding amide as we explained in our previous research (Al-Salami, 2009; Al-Salami et al., 2014). Linking the carboxylic terminal of phthalyl DL-Leucine with the $\mathrm{NH}_{2}$-terminal of sulfa drugs together requires the formation of an amide. This formation of an amid bond can be accomplished in a number way but all require that the carboxylic acid be converted to an activated acyl derivative that is more susceptible to nucleophilic acyl substitution. A particularly good Choise for the acyl derivative is one formed from (DCCI) and the carboxylic acid .

Nucleophilic acyl substitution takes place in the normal addition elimination fashion and produces a urea (derived from carbodiamide) in addition to the desired amide (Al-Salami, 2009; Al-Salami et al., 2014).

\section{MATERIALS AND METHODS}

\section{Expermental \\ Materials and reagents: All the chemicals and solvent used were of Analytical grade (AR) and of higest purity obtainable which included phthalicanhydride (MERCK) DL-Leucine (MERCK), all kinds of sulfa drugs (Aldrich). All solvent used equipped by (BDH) company. The measurements of melting point were done on Bauchi 510 .}


Instrumentation: The solid state FTIR spectra of the compounds were record on shimadzu FT-IR Model $8400 \mathrm{~S}$ spectrophotometer using $\mathrm{KBr}$ pellets in the range $4000-400 \mathrm{~cm}^{-1}$. The spectra of HNMR were done in a brucker spectrophotometer (400 MHZ) and using DMSO-d6 as solvent and TMS as internal standard. Elemental analysis (C, H, N, S) were recorded by Euro vector model $3000 \mathrm{~A}$ (Italy).

Preparation of N-Phthalyl DL-Leucine: In this study, we prepared N-Phthalyl DL-Leucine by the method described by Ing and Fox (Doering and Weil, 1947). An equimoles amounts of DL-Leucine and finely ground phthalic anhydride are heated in oil-bath at 150 for 25 min until frothing ceased. After cooling, the light brown mass was extracted with boiling ether. Hexane was added to the filtered ether extracts until the appearance of white precipitation, recrystallized from cyclohexane. The N-phthalyl DL-Leucine was prepared (melting point) was (118-119) with yield $83 \%$.

Synthesis of compounds (F1-F7): The new compounds (F1-F7) were prepared from conforming phthalyl DL-leucine and different types of sulfa drugs according to literature procedure curni (Curini et al., 2002). The prepataion methods for a compsite can be illustrated as follows:

- F1: 2-(1, 3-dioxoisoindolin-2-yl)-4-methyl-N-(4sulfamoylphenyl) pentanamide

- F2: N-(4-(3, 4-dimethylisoxazole-5-yl) sulfamoyl) phenyl-2-(1,3-dioxoisoindoline-2-yl)4-methyl pentanamide
- $\quad$ F3: 2-(1,3-dioxoisoindolin-2-yl) -4-methyl-N-(4-(N5-methyl-isoxazol-3-yl) sulfamoyl) phenyl ) pentanamide

- F4: 2-(1,3-dioxoisoindoline-2-yl)-4-methyl-N-(4-(Nthiazole-2-yl)sulfamol )penyl)pentanamide.

- $\quad$ F5: Sodium acetyl(4-(2-(1, 3-dioxoisoindoline-2-yl) 4-methly pentanamido) phenyl) sulfaonyl) amide

- F6: 2-(1, 3-dioxoisoindoline-2-yl) 4-methyl-N-(4-(N(pyridin-2-yl) sulfamoyl) phenyl) pentanamide

- F7: 2-(1,3-dioxoisolndoline-2-yl)-4-methyl-N-(4-N(pyrimidin-2-yl) sulfamoyl) phenyl) pentanamide

These compounds (F1-F7) were prepared by mixing the congruous phthalyl DL-leucuie $1 \mathrm{mmol}(0.1722 \mathrm{~g})$ with $1 \mathrm{mmol}$ of sulfanilamide $(0.261 \mathrm{~g})$, sulfaisoxazole $(0.267 \mathrm{~g})$, sulfamethaxazole $(0.253 \mathrm{~g})$, sulfathiazole (0.2553), sulfacetamide sodium ( $0.236 \mathrm{~g})$, sulfapyridine $(0.249 \mathrm{~g})$ and sulfadiazine $(0.250 \mathrm{~g})$, respectively in $50 \mathrm{~mL}$ of ethylacetate, to this stirred solution has been added dropwise solution of DCCI $(0.206 \mathrm{~g}, 1 \mathrm{mmol})$ in $5 \mathrm{~mL}$ ethylacetate over period $20 \mathrm{~min}$ at room temperature with continuous stirring until white precipitate formed (dicyclohexylurea). The solid precipitate was filtered of and the filtrate was washed with 5\% citric acid solution $(10 \mathrm{~mL})$, two layers formed and separation by extraction. The aquatic layer was neglected and the organic layer was taken. The solvent was evaporated and the residue was purified by silica gel column chromatography (eluent ethylacetate: $n$-hexan 2:8). The structural formula, elemental analysis and physical properties were listed and conferred in Table 1 . The synthetic compounds were summarized in Fig. 1.

In vitro antimicrobial activity: The biological activity of the new compounds (F1-F7) were studied against two type of bacteria which included positive bacteria (Staphylococcus aureus) and gram negative bacteria

Table 1: Symbol, structural formula, IUPAC name, analytical and physical data of the synthetic compounds

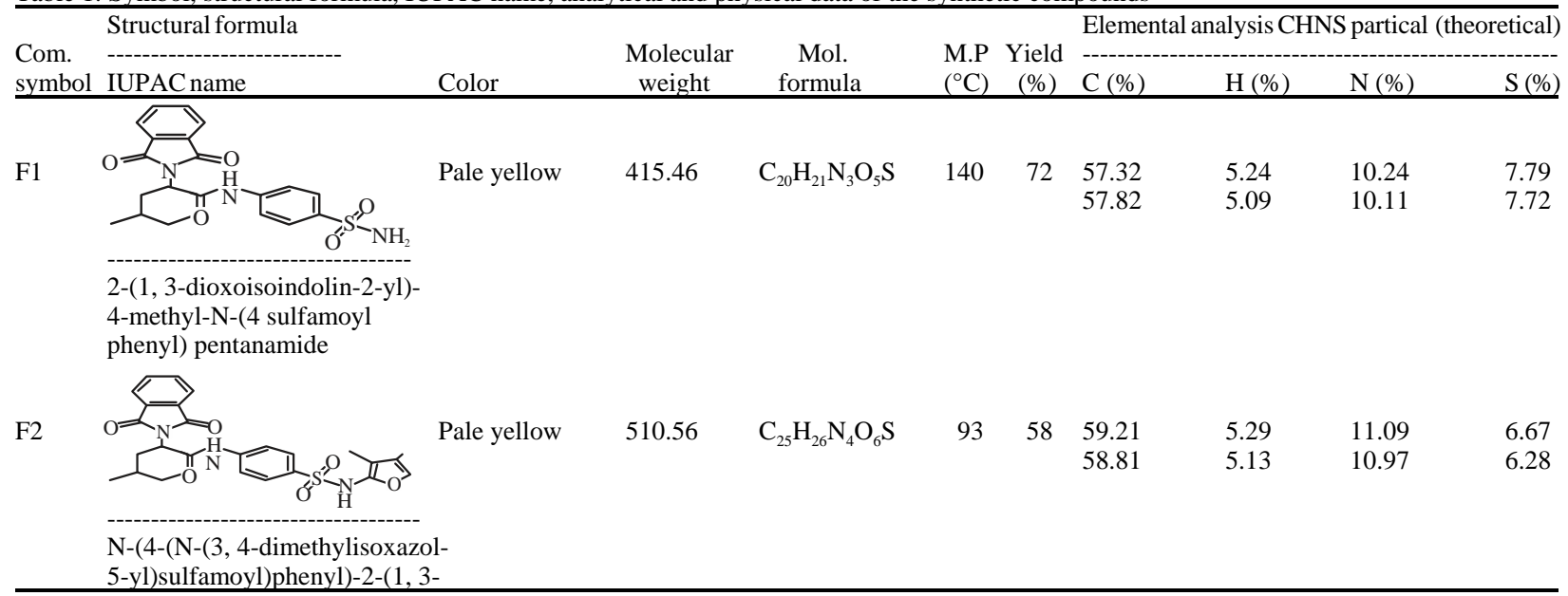


J. Eng. Applied Sci., 14 (Special Issue 9): 10579-10588, 2019

Table 1: Continue

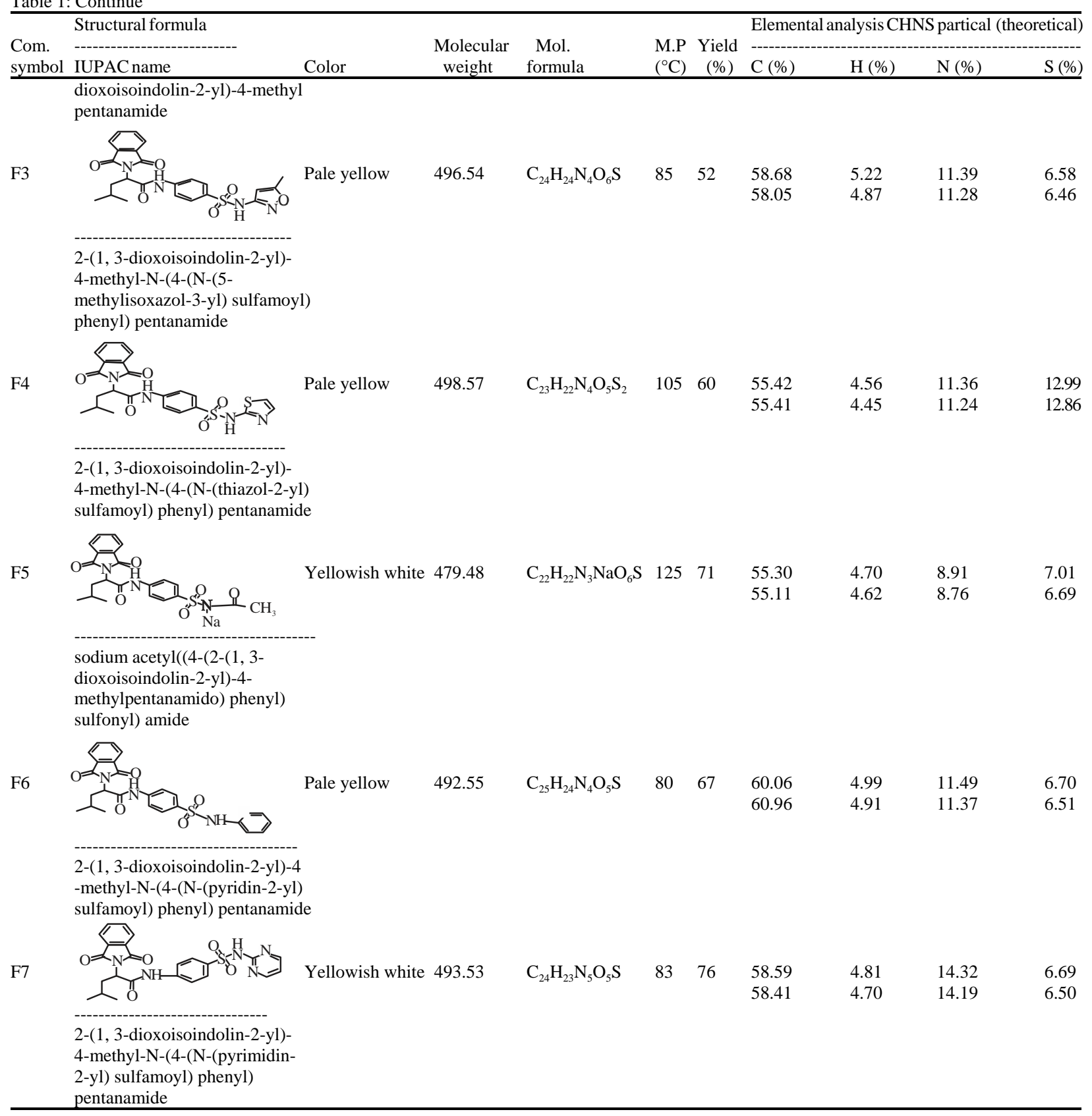

(Aerompnas veroni) by using agar plate diffusion (Al-Salami, 2018). Dimethyl sulfoxide was used as a solvent and as control for disc sensitivity. The antibiotic tetracycline $25 \mathrm{mg} \mathrm{L^{-1 }}$ was used for the purpose of calibration and comparison with the bacteria stuff. Bacteria have been cultureal by providing the appropriate habitat for their growth at $37^{\circ} \mathrm{C}$ for $24 \mathrm{~h}$. This method involves the detection of the zone of inhibition toward the diffusion of microorganism on agar plate. The solution of compounds (F1-F7) were prepared in different concentration to estimated the antibacterial activity by using $0.1 \mathrm{~mL}$ of particular bacterial culture. The plate were incubated for $24 \mathrm{~h}$ at $37^{\circ} \mathrm{C}$ (Al-Salami, 2018). Zone of inhibition were determined in $\mathrm{mm}$. Also, the values of Minimum Inhibitory Concentration (MIC) of these compounds were calculated (Al-Salami, 2018). The MIC can be defined as the lowest concentration of the compound in a media which prevent visible growth of the test bacteria in each concentration $\left(25-300 \mathrm{mg} \mathrm{L}^{-1}\right)$. The MIC is determined by preparing solution of the chemical in vitro at increasing concentrations incubating 
J. Eng. Applied Sci., 14 (Special Issue 9): 10579-10588, 2019
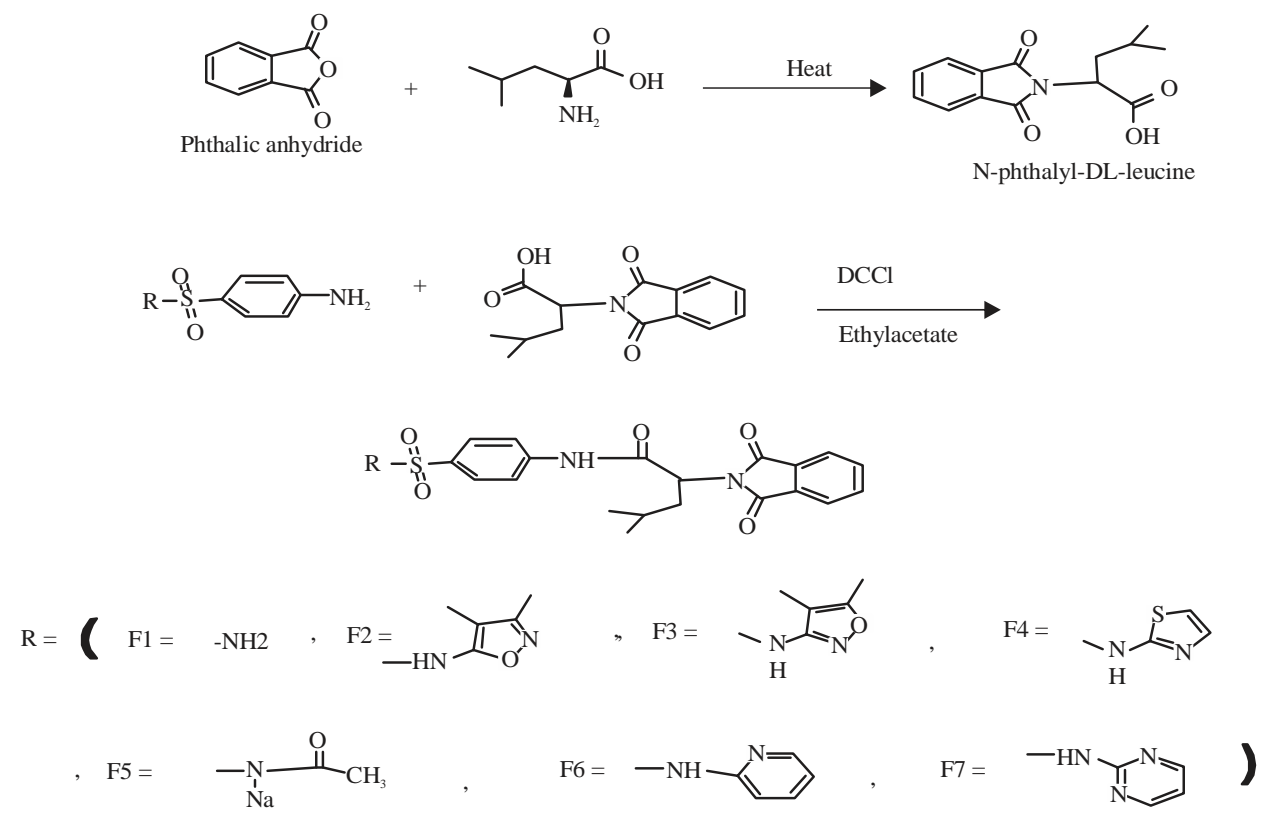

Fig. 1: The synthetic compounds

the solutions with the separate batches of cultured bacteria, and measuring the results using agar dilution or broth microdilution (Andrews, 2001).

\section{RESULTS AND DISCUSSION}

In this research, focus on synthesis of amide from amino acids were these amino acids are classified as a kind of carboxylic acid. The amide compounds are one of the important derivatives of carboxylic acid. The reaction and mechanism of formation of amide from amino acid has already been explaned in our previous work (Al-Salami, 2009; Al-Salami et al., 2014). The mechanism shows that the DCCI works as condensing agent to equip the compatable amide. One of the important analysis in this research was elemental analysis and the outcomes of it shows in Table 1, we will find that there is a great match with the propose structure.

FT-IR spectra: FT-IR spectra data are listed in Table 2 and Fig. 2-4. Derivatives of amino acids such as phthalyl amino acids are characterized by appearance of $\mathrm{OH}$ band but when configured the amide from this derivatives we saw disappearance of the $\mathrm{OH}$ band and instead of that the new amides display a strong band at the range (3381-3327 $\mathrm{cm}^{-1}$ ) which attributed to NH group of amides which attributed to the range $3381-3327 \mathrm{~cm}^{-1}$ of new amides. Also the formation of amide can be characterized by appearance of amide II $(\mathrm{vNH})$ band in the range $\left(1658-1593 \mathrm{~cm}^{-1}\right.$ while the amide $\mathrm{I}(\mathrm{vC}=\mathrm{O})$ appear as a strong bands in the range $1685-1616 \mathrm{~cm}^{-1}$.
Furthermore, the new amides contain sulfa component in particular contain $\mathrm{SO}_{2}$ moiety appears featured bandsat the range 1388-1336 and in 1188-1138 $\mathrm{cm}^{-1}$ which assigned to asymmetrical and symmetrical stretching vibration, respectively of $\mathrm{SO}_{2}$ (Al-Salami, 2009; Al-Salami et al., 2014). Also the sulfa component possess another group which was $\mathrm{C}=\mathrm{N}$ moiety of aromatic ring, thus, the band of $\mathrm{C}=\mathrm{N}$ appear at the range (1329-1333 $\left.\mathrm{cm}^{-1}\right)$. In addition, appearance of bands at the range $1776-1772$ and at $1708-1714 \mathrm{~cm}^{-1}$ which attributed to $\mathrm{C}=\mathrm{O}$ anhydride moiety.

HNMR spectra: The HNMR spectral data of new amides (F1-F7) have been summarized in Table 3. The results gave a great match to the expected composition of the structure of these new amides. The spectra of selected HNMR were shown in Fig. 5-7. From HNMR spectrum all compounds (F1-F7) displays a singlet signal at 10.2-10.36 ppm attributed to proton of NHC $=$ O proton which indicates the formation of corresponding amides due to condensation of amino acids drivatives and sulfa drugs (Al-Salami, 2018). Also all synthetic amides except F5 exhibit a broad signal which can assigned to $\mathrm{SO}_{2} \mathrm{NH}$ proton that affiliated to sulfa component (Ebrahimi et al., 2013; Kumar and Rani, 2011). As we observe from HNMR the spectrum of compound F1 display a broad signal at $10.29 \mathrm{ppm}$ which attributed to the two protons terminal amine group $\mathrm{NH}_{2}$ which belong to components of sulfa drugs (Al-Salami, 2009, 2018). Also, the multiple signals that appear in the range (6.09-8.41 ppm can be assigned to the aromatic protons 
J. Eng. Applied Sci., 14 (Special Issue 9): 10579-10588, 2019

Table 2: FT-IR of synthetic amide ( $\mathrm{cm}^{-1}, \mathrm{KBr}$ disc) (vs: very strong, $\mathrm{s}:$ strong, $\mathrm{m}$ : medium, w: weak, br: broad)

\begin{tabular}{|c|c|c|c|c|c|c|c|c|c|c|}
\hline Comp. & $v_{\mathrm{N}-\mathrm{H}}$ & $\mathrm{v}_{\mathrm{C}-\mathrm{H}}$ aromatic & $v_{\mathrm{C}-\mathrm{H}}$ aliphatic asy-sym. & $v_{\mathrm{C}=0}$ anhydride & $v_{\mathrm{C}=\mathrm{O}}$ amide-I & $v_{\mathrm{N}-\mathrm{H}}$ amide-II & $v_{\mathrm{C}=\mathrm{N}}$ sulfa & $v_{\mathrm{S}=\mathrm{O}}$ asym. & $v_{\mathrm{s}=0} \mathrm{Sym}$ & $v_{\mathrm{S}-\mathrm{N}}$ \\
\hline$\overline{\mathrm{F} 1}$ & $3369 \mathrm{~s}$ & $3059 \mathrm{w}$ & 2995 m 2929 & $1772 \mathrm{~m} 1714 \mathrm{~s}$ & $1656 \mathrm{~s}$ & $1649 \mathrm{w}$ & $1531 \mathrm{~m}$ & $1382 \mathrm{~s}$ & $1155 \mathrm{~m}$ & $893 w$ \\
\hline F2 & $3373 \mathrm{~m}$ & $3059 \mathrm{w}$ & 2956 s 2933 s & $1776 \mathrm{~m} 1712 \mathrm{~m}$ & $1683 \mathrm{~s}$ & $1647 \mathrm{w}$ & $1529 \mathrm{~s}$ & $1386 \mathrm{~m}$ & $1188 \mathrm{~m}$ & $923 \mathrm{w}$ \\
\hline F3 & $3358 \mathrm{~m}$ & $3062 \mathrm{~m}$ & 2958 s 2933 s & 1774 m 1712 s & $1616 \mathrm{~s}$ & $1593 \mathrm{w}$ & $1533 \mathrm{~m}$ & $1388 \mathrm{~s}$ & $1165 \mathrm{~m}$ & $931 \mathrm{w}$ \\
\hline F4 & $3327 \mathrm{~m}$ & $3111 \mathrm{w}$ & 2929 m 2852 m & 1774 s 1712 s & $1674 \mathrm{~m}$ & $1658 \mathrm{w}$ & $1533 \mathrm{~s}$ & $1386 \mathrm{~s}$ & $1145 \mathrm{~s}$ & $929 w$ \\
\hline F5 & $3381 \mathrm{~m}$ & $3061 \mathrm{w}$ & 2929 s 2854 m & 1772 m 1714 s & $1685 \mathrm{~m}$ & $1656 \mathrm{~m}$ & $1530 \mathrm{~m}$ & $1386 \mathrm{~m}$ & $1155 \mathrm{~m}$ & $858 w$ \\
\hline F6 & $3365 \mathrm{~m}$ & $3057 \mathrm{w}$ & 2929 s 2854 m & 1774 w 1712 m & $1656 \mathrm{~m}$ & $1631 \mathrm{~m}$ & $1533 \mathrm{~m}$ & $1386 \mathrm{~s}$ & $1138 \mathrm{~m}$ & $945 \mathrm{w}$ \\
\hline F7 & $3373 \mathrm{w}$ & $3035 \mathrm{w}$ & 2933 s 2854 m & $1776 \mathrm{~m} 1708 \mathrm{~s}$ & $1678 \mathrm{~m}$ & $1658 \mathrm{~m}$ & $1533 \mathrm{~m}$ & $1336 \mathrm{~s}$ & $1161 \mathrm{~s}$ & $947 \mathrm{~m}$ \\
\hline
\end{tabular}

Table 3: 1HNMR spectral data of synthetic amides (F1-F7)

\begin{tabular}{|c|c|c|}
\hline Symbol of com. & Structural formula & Chemical shift $\delta(\mathrm{ppm})$ \\
\hline$\overline{\mathrm{F} 1}$ & & $\begin{array}{l}\text { 10.29(s, 1H, NH-CO), 6.88-7.73(m, 8H, Ar), } 10.29\left(\mathrm{br}, 2 \mathrm{H}, \mathrm{NH}_{2}\right)_{\text {sulfa }}, 5.16(\mathrm{t}, \mathrm{H}, \mathrm{CH}), 2.075 \\
\left.\text { (dd, } 2 \mathrm{H}, \mathrm{CH}_{2}\right), 1.65(\mathrm{~m}, \mathrm{H}, \mathrm{CH}), 1.24\left(\mathrm{~d}, 6 \mathrm{H}, \mathrm{CH}_{3}\right)\end{array}$ \\
\hline F2 & & $\begin{array}{l}10.36(\mathrm{~s}, 1 \mathrm{H}, \mathrm{NH}-\mathrm{CO}), 6.10-7.90(\mathrm{~m}, 8 \mathrm{H}, \mathrm{Ar}), 11.0\left(\mathrm{br}, \mathrm{H}, \mathrm{SO}_{2} \mathrm{NH}\right)_{\text {Sulfa, }}, 2.07\left(\mathrm{~s}, 3 \mathrm{H}, \mathrm{CH}_{3}\right)_{\text {sulfa }} \text {, } \\
2.081\left(\mathrm{~s}, 3 \mathrm{H}, \mathrm{CH}_{3}\right)_{\text {sulfa }}, 4.79(\mathrm{t}, \mathrm{H}, \mathrm{CH}), 2.079\left(\mathrm{dd}, 2 \mathrm{H}, \mathrm{CH}_{2}\right), 1.23(\mathrm{~m}, \mathrm{H}, \mathrm{CH}), 0.90 \\
\left(\mathrm{~d}, 6 \mathrm{H}, \mathrm{CH}_{3}\right)\end{array}$ \\
\hline F3 & & $\begin{array}{l}10.36(\mathrm{~s}, 1 \mathrm{H}, \mathrm{NH}-\mathrm{CO}), 6.09-7.79(\mathrm{~m}, 9 \mathrm{H}, \mathrm{Ar}), 11.09\left(\mathrm{br}, \mathrm{H}, \mathrm{SO}_{2} \mathrm{NH}\right)_{\text {Sulfa }}, 2.29(\mathrm{~s}, \\
3 \mathrm{H}, \mathrm{CH} 3)_{\text {Sulfa }}, 4.79(\mathrm{t}, \mathrm{H}, \mathrm{CH}), 2.0759\left(\mathrm{dd}, 2 \mathrm{H}, \mathrm{CH}_{2}\right), 1.34(\mathrm{~m}, \mathrm{H}, \mathrm{CH}), 0.92\left(\mathrm{~d}, 6 \mathrm{H}, \mathrm{CH}_{3}\right)\end{array}$ \\
\hline F4 & & $\begin{array}{l}10.24(\mathrm{~s}, 1 \mathrm{H}, \mathrm{NH}-\mathrm{CO}), 6.59-7.93(\mathrm{~m}, 10 \mathrm{H}, \mathrm{Ar}), 11.02\left(\mathrm{br}, \mathrm{H}, \mathrm{SO}_{2} \mathrm{NH}\right)_{\text {Sulfa }}, 3.92(\mathrm{t}, \mathrm{H}, \mathrm{CH}) \text {, } \\
2.0759(\mathrm{dd}, 2 \mathrm{H}, \mathrm{CH}), 1.62(\mathrm{~m}, \mathrm{H}, \mathrm{CH}), 0.90\left(\mathrm{~d}, 6 \mathrm{H}, \mathrm{CH}_{3}\right)\end{array}$ \\
\hline F5 & & $\begin{array}{l}10.34(\mathrm{~s}, 1 \mathrm{H}, \mathrm{NH}-\mathrm{CO}), 6.18-7.76(\mathrm{~m}, 8 \mathrm{H}, \mathrm{Ar}), 1.69\left(\mathrm{~s}, 3 \mathrm{H}, \mathrm{CH}_{3}\right)_{\text {sulfa }}, 4.8(\mathrm{t}, \mathrm{H}, \mathrm{CH}) \\
2.11\left(\mathrm{dd}, 2 \mathrm{H}, \mathrm{CH}_{2}\right), 1.45(\mathrm{~m}, \mathrm{H}, \mathrm{CH}), 0.92\left(\mathrm{~d}, 6 \mathrm{H}, \mathrm{CH}_{3}\right)\end{array}$ \\
\hline F6 & & $\begin{array}{l}10.30(\mathrm{~s}, 1 \mathrm{H}, \mathrm{NH}-\mathrm{CO}), 6.71-8.09(\mathrm{~m}, 12 \mathrm{H}, \mathrm{Ar}), 11.02\left(\mathrm{br}, \mathrm{H}, \mathrm{SO}_{2} \mathrm{NH}\right)_{\text {Sulfa }}, 4.66(\mathrm{t}, \mathrm{H}, \mathrm{CH}) \text {, } \\
2.071\left(\mathrm{dd}, 2 \mathrm{H}, \mathrm{CH}_{2}\right), 1.46(\mathrm{~m}, \mathrm{H}, \mathrm{CH}), 0.961\left(\mathrm{~d}, 6 \mathrm{H}, \mathrm{CH}_{3}\right)\end{array}$ \\
\hline F7 & & $\begin{array}{l}10.28(\mathrm{~s}, 1 \mathrm{H}, \mathrm{NH}-\mathrm{CO}), 6.92-8.41(\mathrm{~m}, 7 \mathrm{H}, \mathrm{Ar}), 11.013\left(\mathrm{br}, \mathrm{H}, \mathrm{SO}_{2} \mathrm{NH}\right)_{\text {sulfa }}, 5.01(\mathrm{t}, \mathrm{H}, \mathrm{CH}) \text {, } \\
2.08\left(\mathrm{dd}, 2 \mathrm{H}, \mathrm{CH}_{2}\right), 1.60(\mathrm{~m}, \mathrm{H}, \mathrm{CH}), 0.99\left(\mathrm{~d}, 6 \mathrm{H}, \mathrm{CH}_{3}\right)\end{array}$ \\
\hline
\end{tabular}

of these new amides. Furthermore, all the synthesized compounds have been shown signals to $\mathrm{CH}_{3}, \mathrm{CH}_{2}$ and $\mathrm{CH}$ protons with different locations as shown in Table 3 , the appearance and interpreted of these signals depend on the site of these components in the organic molecule. Also the signal of $\mathrm{CH}_{3}$ (sulfa moiety) protons in compound s F2 and F3 where observed at 2,07 and $2.29 \mathrm{ppm}$ (Ahmad et al., 2015).

Antibacterial testing: In vitro antimicrobial activity of the compounds (F1-F7) have been screened against two, kinds of bacteria, Gram positive (S.aurous) and Gram negative (A,Veronil) as shown in Table 4, Fig. 8. DMSO is used as negative control and solvent. The antibiotic tetracycline $25 \mathrm{~g} \mathrm{~L}^{-1}$ have been used as a positive standared. The stock solution from each compound was prepared. Serial dilations of experimental compounds were prepared in different conc. The 25, 50, 100, 150, 200, 250, $300 \mathrm{mg} \mathrm{L}^{-1}$ in order to calculate the value of Minimum Inhibition Concentration (MIC). Antibacterial activities of each compound were estimated in Table 4. From the results of antibacterial screening of these amides, it has been observed that all the synthesized compounds have a variable antibacterial activity agains the two kinds of microorganism, especially, against Gram-negative bacteria, than another type Gram-positive even in low concentration. On the other hand, we note an increase in the antimicrobial activity whenever the concentration of these amides increase. Also, from the current study and the results we observed that compound 


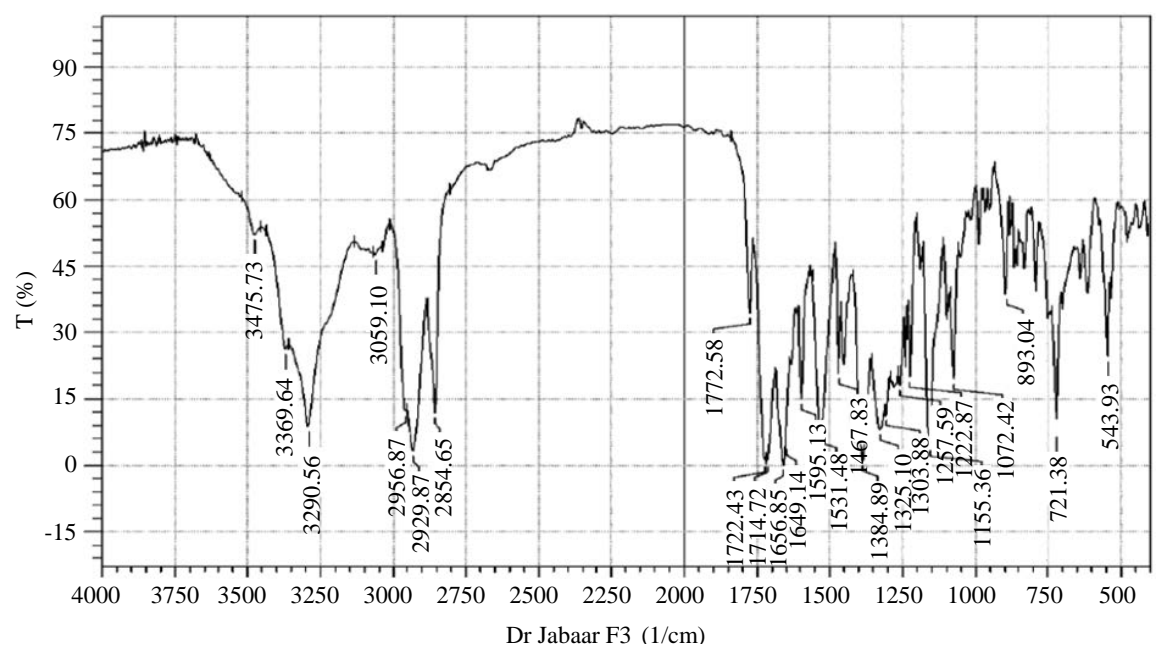

Fig. 2: IR spectrum of F1 compounds

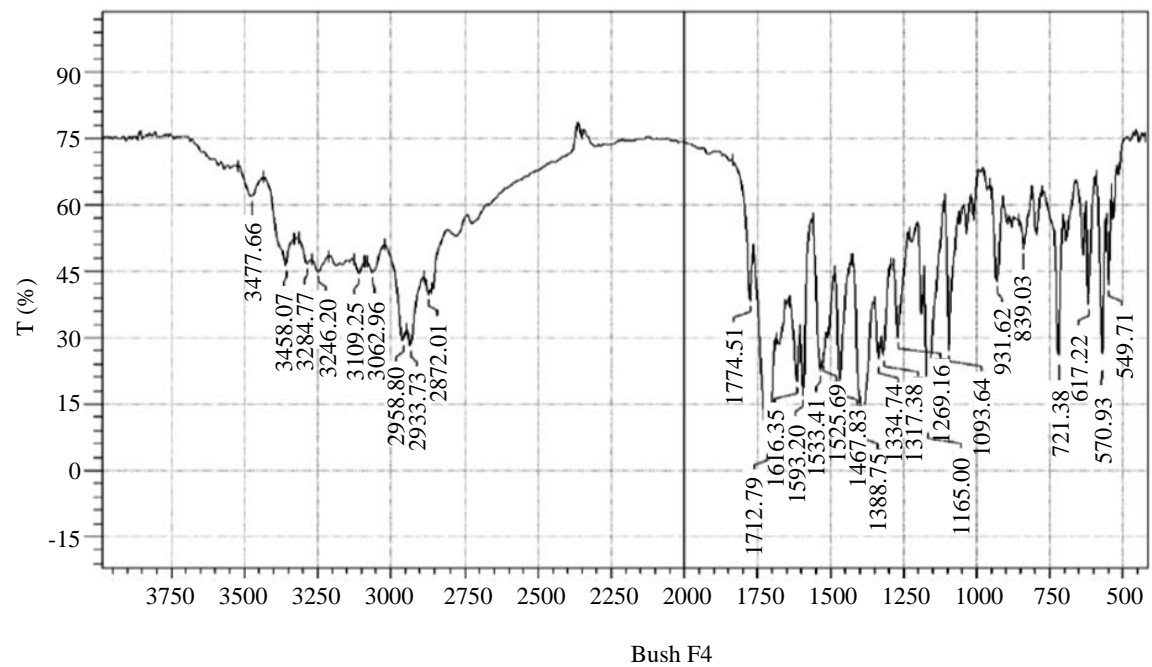

Fig. 3: IR spectrum of F3 compound

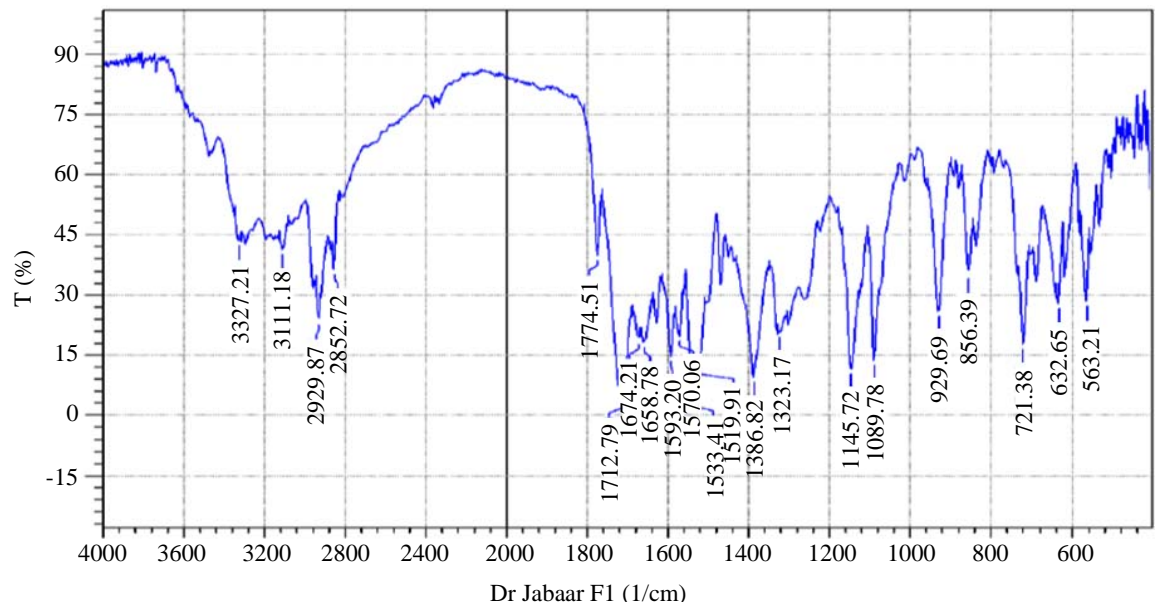

Fig. 4: IR spectrum of F4 compounds 


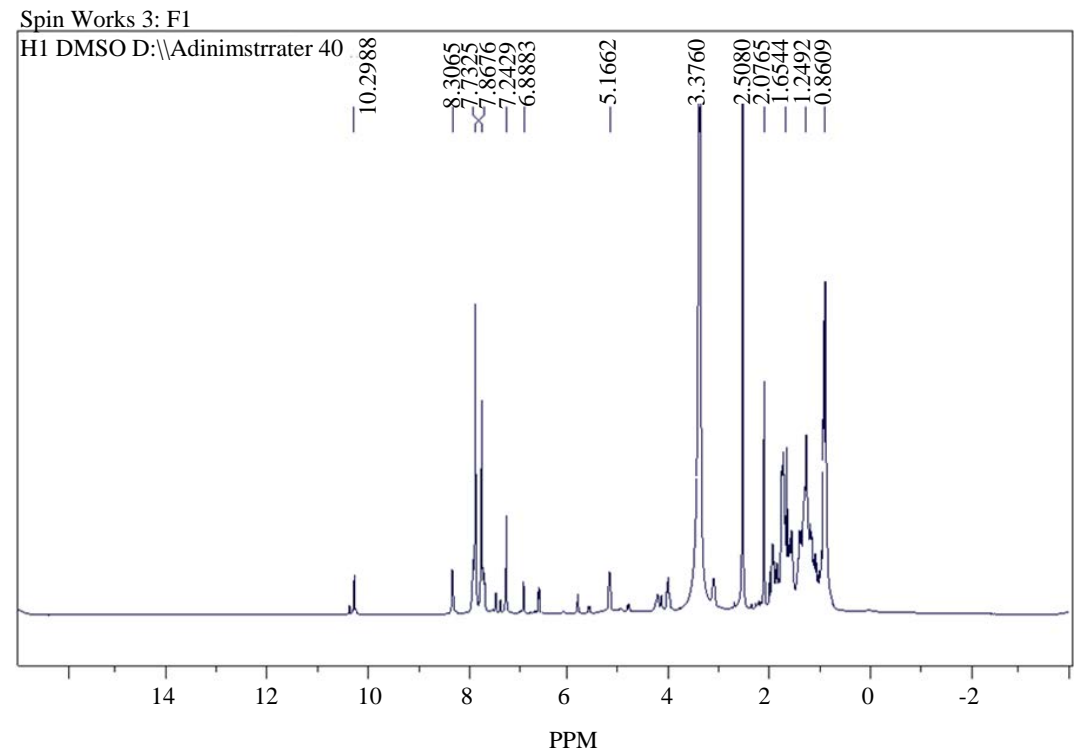

Fig. 5: 1HNMR spectrum of F1 compound

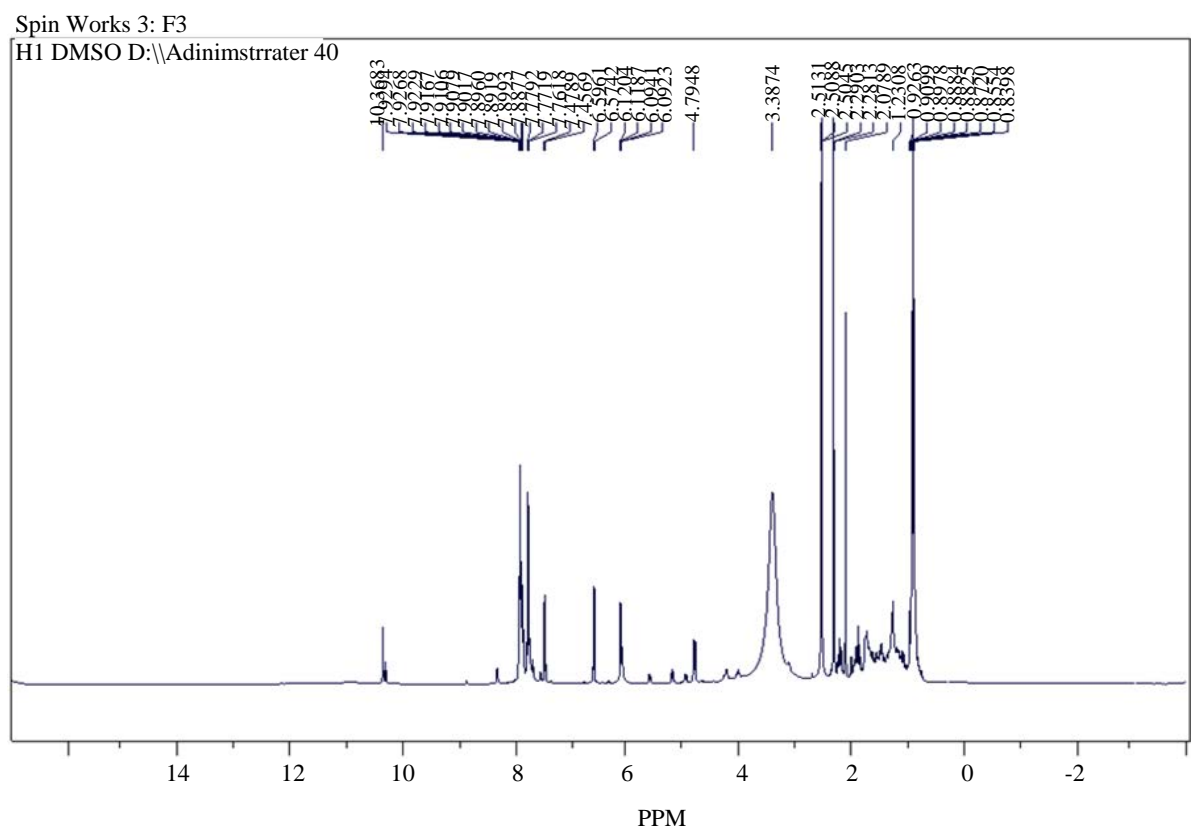

Fig. 6: 1HNMR spectrum of F3 compound

F4 and F6 owned a better activity than another compounds against the two kinds of microorganisms. The observation of antimicrobial inspection indicate that these synthesized amides can affect on the cell walls of bacteria which consists of two layers, the peptidogly can which is located outside of cytoplasmic membrane and the another layer which is lipid bilayer membrane which is characterized by the bacterial in general from the another kinds of organism. When compared with tow kinds (-ve) and $(+\mathrm{v})$, the cell wall of gram-positive bacteria is thick because the matrix substance in this wall contain polysaccharides, piptidoglycan which known as murein layer is the main component of this wall and lipotieichoic acid on the contrary the cell wall of Gram-negative bacteria is thin which contain a thin peptidoglycan layer (Demchick and Koch, 1996), so, these materials such as the synthesized compounds can penetrate the wall easily and smoothly thus, affecting the osmotic pressure (Yabe et al., 2011). In addition, the wall membrane of these bacteria formulated with 
J. Eng. Applied Sci., 14 (Special Issue 9): 10579-10588, 2019

Table 4: In vitro activity and Minimum Inhibitory Concentration (MIC) result of the synthesized compounds (F1-F7)

Dimeter of inhibition zone (mm) Staphylococcus aurous

Concentration (mg L ${ }^{-1}$ )

\begin{tabular}{|c|c|c|c|c|c|c|c|c|}
\hline \multirow{2}{*}{ Compound } & \\
\hline & 25 & 50 & 100 & 150 & 200 & 250 & 300 & MIC \\
\hline$\overline{\mathrm{F} 1}$ & $\mathrm{NI}^{*}$ & 4 & 7 & 11 & 15 & 21 & 26 & 50 \\
\hline F2 & NI & NI & 4 & 7 & 11 & 17 & 20 & 100 \\
\hline F3 & NI & NI & $\mathrm{NI}$ & 5 & 8 & 13 & 19 & 150 \\
\hline $\mathrm{F} 4$ & 4 & 6 & 11 & 16 & 20 & 24 & 39 & 25 \\
\hline F5 & NI & NI & NI & 4 & 7 & 12 & 19 & 150 \\
\hline F6 & 5 & 9 & 15 & 18 & 22 & 29 & 35 & 25 \\
\hline F7 & 4 & 7 & 13 & 17 & 20 & 27 & 31 & 25 \\
\hline Tetracycline & 4 & 6 & 10 & 14 & 18 & 22 & 27 & 25 \\
\hline Compound & \multicolumn{8}{|c|}{ Dimeter of inhibition zone (mm) Aerompnas veronil } \\
\hline
\end{tabular}

Concentration (mg L $\left.{ }^{-1}\right)$

\begin{tabular}{|c|c|c|c|c|c|c|c|c|}
\hline & 25 & 50 & 100 & 150 & 200 & 250 & 300 & MIC \\
\hline$\overline{\mathrm{F} 1}$ & $\mathrm{NI}$ & $\mathrm{NI}$ & 4 & 7 & 12 & 18 & 23 & 100 \\
\hline $\mathrm{F} 2$ & 6 & 9 & 16 & 20 & 27 & 33 & 42 & 25 \\
\hline F3 & 5 & 7 & 13 & 19 & 22 & 29 & 35 & 25 \\
\hline $\mathrm{F} 4$ & 4 & 6 & 11 & 17 & 21 & 27 & 31 & 25 \\
\hline F5 & NI & 7 & 12 & 18 & 25 & 29 & 35 & 50 \\
\hline F6 & 5 & 8 & 15 & 21 & 27 & 35 & 40 & 25 \\
\hline F7 & NI & 5 & 9 & 16 & 20 & 27 & 33 & 50 \\
\hline Tetracycline & 5 & 8 & 11 & 16 & 17 & 26 & 29 & 25 \\
\hline
\end{tabular}

NI*: No Inhibition

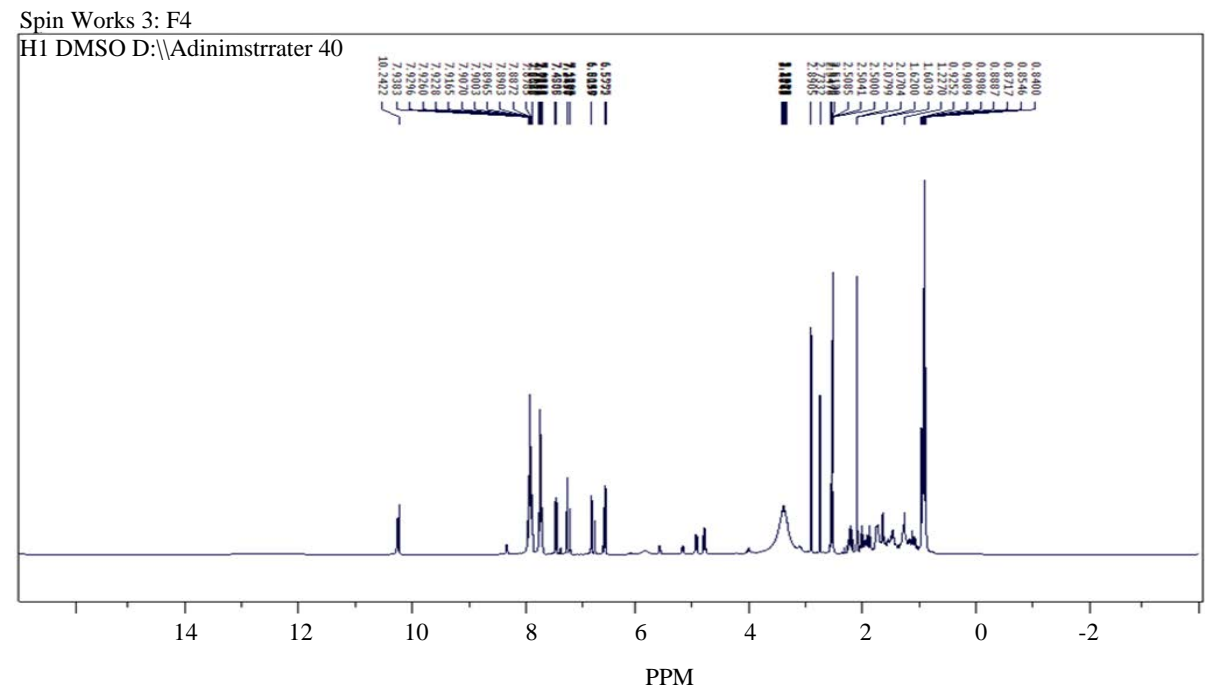

Fig. 7: 1HNMR spectrum of F4 compound

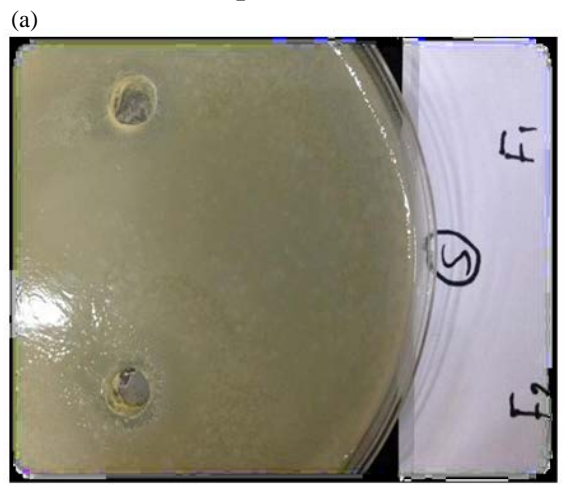

(b)

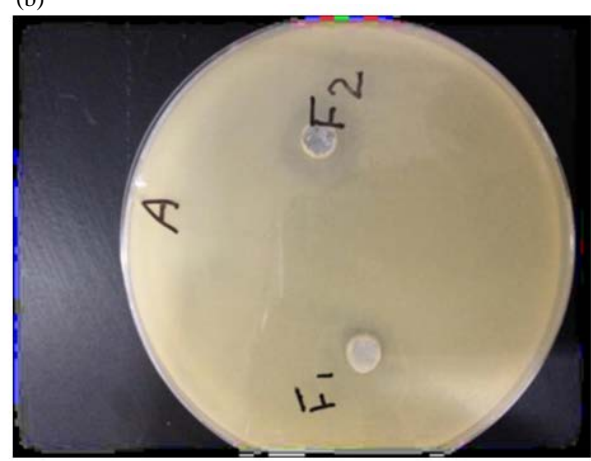

Fig. 8(a, b): The antibacterial activity of compounds F1 and F2 
peptidolycans long chain of carbohydrates cross-linked by stumpy peptides and therefore, if any component abnormal which created or synthesized can inserted into these peptides will affect and the fobidding these bacteria from multiply and breakdown the formation of the cross-links thus, leading to shredding that wall (Yabe et al., 2011).

\section{CONCLUSION}

In this study, emphasis was placed on the utilization of amino acid derivatives such as phthalyl DL-leucine and sulfa drugs to synthesized new amides by condensation reaction. This reaction can be done by nucleophilic acyl substitution reaction by using N, N-Dicyclohexylcarbodiimide (DCCI) as condensation reagent in order to accelerated the procces of condensation. These new synthesized amides have also been characterized based on elemental analysis, FT-IR and HNMR spectra. The analysis confirmed the composition and structures of these newly amides. Also the antibacterial activity have been examined for these newly compounds by using two types of bacteria, negative gram stain (Aermpans veronil) and against positive gram (Staphlococcus aureus) by using different concentration of these compounds.

From the biological results it has been observed that these compounds show slightly active against Gram positive and have abetter activity toward the Gram negative depend on the instillation of a cell wall of microorganism. In fact these newly amides showed excellent effectiveness at high concentrations (300 $\mathrm{mg} \mathrm{L}^{-1}$ ) especially, against Gram-negative stain. Also the MIC was done by compare these newly amides with tetracycline as standard to demonstrate the capacity of these newly amide against some types of bacteria.

\section{REFERENCES}

Ahmad, T., F. Kandil and C. Moustapha, 2015. Preparation and characterization of some new Azo dyes, azomethine dyes and heterocyclic-schiff bases derivatives. AASCIT. J. Chem., 2: 24-31.

Al-Fregi, A.A., A.L. Al-Fadhly and B.K. Al-Salami, 2017. Synthesis, characterization and biological activity study of some new palladium (II) complexes containing amine or azomethine groups. Eur. J. Chem., 8: 155-161.

Al-Salami, B.K., 2009. DCC promoted condensation reaction of N-phthalylamino acids with Sulphanilamide. Misan J. Acodemic Stud., 8: 18-25.
Al-Salami, B.K., 2018. Synthesis, characterization and antimicrobial activity studies of new amide derivatives from benzoyl derivatives of amino acid and selected sulfa drugs by using DCCI. Der Chem. Sin., 9: 762-772.

Al-Salami, B.K., H.H. Sabah and H.K. Moussa, 2014. Condensation of some N-phthalylaminoacid with selected sulfa drugs by using DCC as condensing agent. Res. J. Pharm. Biol. Chem. Sci., 5: 1443-1456.

Al-Salami, B.K., R.A. Gata and K.A. Asker, 2017. Synthesis spectral, thermal stability and bacterial activity of schiff bases derived from selective amino acid and their complexes. Adv. Appl. Sci. Res., 8: 4-12.

Andrews, J.M., 2001. Determination of minimum inhibitory concentrations. J. Antmicrob. Chemother., 48: 5-16.

Bruice, P.Y., 2004. Essential Organic Chemistry. Pearson Edition, London, England, Pages: 439.

Curini, M., F. Epifano, F. Maltese and M.C. Marcotullio, 2002. Novel chiral Schiff base ligands from amino acid amides and salicylaldehyde. Tetrahedron Lett., 43: 3821-3823.

Demchick, P. and A.L. Koch, 1996. The permeability of the wall fabric of Escherichia coli and Bacillus subtilis. J. Bacterial., 178: 768-773.

Doering, W.E. and R.A.N. Weil, 1947. Electrophilic reactions of 2-and 4-vinylpyridines. J. Am. Chem. Soc., 69: 2461-2466.

Ebrahimi, H., J.S. Hadi and H.S. Al-Ansari, 2013. A new series of Schiff bases derived from sulfa drugs and indole-3-carboxaldehyde: Synthesis, characterization, spectral and DFT computational studies. J. Mol. Struct., 1039: 37-45.

Fox, M.A. and J.K. Whitesell, 2004. Organic Chemistry. 3rd Edn., Jones and Bartlett Publisher, Burlington, Massachusetts, USA., ISBN-13:978-0763721978, Pages: 1140.

Hassan, A., N. Girgis, J. Sippel, K. Sorensen and M. Yassin, 1974. Use of sulfadiazine in the prophylaxis of group A meningococcal carriers in Egypt. Trop. Geog. Med., 26: 87-90.

Kumar, P.P. and B.L. Rani, 2011. Synthesis and characterization of new Schiff bases containing pyridine moiety and their derivatives as antioxidant agents. Intl. J. ChemTech Res., 3: 155-160.

Lipmann, F., R.D. Hotchkiss and R.J. Dubos, 1941. The occurrence of D-amino acids in gramicidin and tyrocidine. J. Biol. Chem., 141: 163-169. 
Otten, H., 1986. Domagk and the development of the sulphonamides. J. Antimicrob. Chemother., 17: 689-690.

Schabel, F.M., H.R. Reames and R.D. Housewright, 1946. The use of sulfadiazine and penicillin for treatment of experimental anthrax. J. Infect. Dis., 79: 141-147.

Tilles, S.A., 2001. Practical issues in the management of hypersensitivity reactions: Sulfonamides. South. Med. J., 94: 817-824.
Yabe, S., Y. Aiba, Y. Sakai, M. Hazaka and A. Yokota, 2011. Thermogemmatispora onikobensis gen. nov., sp. nov. and Thermogemmatispora foliorum sp. nov., isolated from fallen leaves on geothermal soils and description of Thermogemmatisporaceae fam. Nov. and Thermogemmatisporales ord. nov. within the class Ktedonobacteria. Intl. J. Syst. Evol. Microbial., 61: 903-910. 